\title{
APLIKASI REGRESI LOGISTIK BINER UNTUK MENGETAHUI DETERMINAN STATUS INISIASI MENYUSU DINI (IMD) WANITA USIA 15-49 TAHUN DI PROVINSI SUMATERA UTARA \\ (Binary Logistic Regression Aplication To Know The Determinants of Early Breastfeeding Initattion (EBI) of Women Age 1-49 Years Old In North Sumatera)
}

\author{
Hafidya Hansari ${ }^{1}$, Budyanra ${ }^{2}$ \\ Politeknik Statistika STIS ${ }^{1}$ \\ Politeknik Statistika STIS² \\ Jl. Otto Iskandardinata No. 64C, Jakarta - 13330 \\ E-mail: 111709723@stis.ac.id
}

\begin{abstract}
ABSTRAK
Kematian bayi merupakan salah satu indikator yang digunakan untuk mengukur derajat kesehatan suatu negara. WHO menyatakan bahwa dua per tiga kematian bayi terjadi pada masa neonatal. Salah satu cara untuk menurunkan kematian neonatal adalah dengan menerapkan Inisiasi Menyusu Dini (IMD). Persentase IMD di Indoensia adalah sebesar 56,5 persen, sehingga membuat Indonesia mendapat kategori baik menurut WHO. Akan tetapi, penerapan IMD di Indonesia masih belum merata. Provinsi Sumatera Utara merupakan provinsi dengan persentase IMD terendah dari tahun 2012 hingga tahun 2017. Pada tahun 2017 persentase IMD di Provinsi Sumatera Utara hanya sebesar 24,2 persen hal ini menyebabkan Provinsi Sumatera Utara berada pada kategori buruk menurut WHO. Tujuan penelitian ini adalah mengetahui gambaran umum status IMD Wanita Usia 15-49 tahun berdasarkan karakteristiknya, mengetahui variabel-variabel yang memengaruhi status IMD di Provinsi Sumatera Utara tahun 2017 dan kecenderungannya Data yang digunakan adalah data mentah SDKI 2017. Metode yang digunakan adalah regresi logistik biner. Hasil yang diperoleh yaitu diperkirakan terdapat sebesar 28,3 persen ibu di Provinsi Sumatera Utara tahun 2017 yang telah melaksanakan IMD dalam waktu kurang dari satu jam setelah melahirkan. Variabel paritas ibu, berat badan bayi saat lahir, metode persalinan dan tingkat pendidikan suami merupakan variabel yang memengaruhi status IMD di Provinsi Sumatera Utara tahun 2017. Serta ibu yang memiliki kecenderungan lebih tinggi untuk melakukan IMD adalah ibu yang memiliki jumlah anak lebih dari satu (multipara), memiliki bayi yang lahir dengan berat badan normal, melakukan persalinan secara normal dan memiliki suami berpendidikan tinggi (SMA keatas).
\end{abstract}

Kata kunci: IMD, regresi logistik biner, SDKI 2017, Sumatera Utara

\section{ABSTRACT}

Infant mortality is one indicator used to measure the health status of a country. WHO states that twothirds of infant deaths occur in the neonatal period. One way to reduce neonatal mortality is to implement an Early Breastfeeding Initiation (EBI). The percentage of EBI in Indonesia is 56.5 percent, making Indonesia a good category according to WHO. However, the implementation of EBI in Indonesia is still uneven. North Sumatera Province is the province with the lowest percentage of EBI from 2012 to 2017. In 2017 the percentage of EBI in North Sumatera Province was only 24.2 percent, causing North Sumatera Province to be in a bad category according to WHO. The purpose of this study was to determine the general picture of EBI status for women aged 15-49 years based on its characteristics, find out the variables that influence the status of EBI in the Province of North Sumatera in 2017 and the trends The data used are raw IDHS 2017. Analyzed using binary logistic regression. The results obtained are estimated that there were 28,3 percent of mothers in North Sumatera Province in 2017 who had carried out EBI in less than one hour after giving birth. Mother parity, baby's weight at birth, delivery method and husband's education level are variables that influence the status of EBI in the Province of North Sumatera in 2017. And mothers who have a higher tendency to do EBI are mothers who have more than one child (multiparous) ), have babies born with normal weight, have normal deliveries and have a highly educated husband (high school and above). 
Keywords: EBI, binary logistics regression, IDHS 2017, North Sumatera.

\section{PENDAHULUAN}

Kematian bayi merupakan salah satu indikator yang digunakan untuk mengukur derajat kesehatan suatu negara. WHO menyatakan bahwa dua per tiga kematian bayi terjadi pada masa neonatal. Angka Kematian Neonatal (AKN) Indonesia pada tahun 2017 adalah sebesar 15 kematian per 1.000 kelahiran hidup, atau dapat dikatakan bahwa 1 dari 67 anak meninggal dalam bulan pertama kehidupannya. Angka tersebut masih jauh dari target AKN yang ditargetkan dalam Sustainable Development Goals (SDGs) tujuan ketiga, yaitu sebesar 12 per 1000 kelahiran hidup (United Nation, 2015). Angka tersebut membuat Indonesia menempati posisi peringkat keempat dengan angka kematian neonatal tertinggi di Asia Tenggara setelah Myanmar, Timor Leste, dan Filipina. Masih tingginya angka kematian neonatal di Indonesia menunjukkan kualitas derajat kesehatan masyarakat yang masih rendah di Indonesia. Kualitas kesehatan yang rendah akan dapat memberikan dampak pada rendahnya kualitas sumber daya manusia yang dihasilkan, hal ini akan menjadi penghalang bagi Indonesia untuk mencapai tujuan pembangunan yang telah ditetapkan.

Dua per tiga kematian neonatal disebabkan oleh praktik pemberian makanan yang kurang tepat pada bayi. Sehingga salah satu cara yang paling efektif untuk mengurangi angka kematian neonatal adalah dengan memberikan ASI dalam 1 jam pertama setelah bayi lahir dan pemberian ASI Eksklusif selama 6 bulan pertama diikuti dengan terus memberi ASI sampai usia 2 tahun atau lebih bersama dengan makanan pendamping ASI. Inisiasi Menyusu Dini (IMD) adalah menyusu dalam 1 jam setelah kelahiran, bayi diletakkan di dada ibu segera setelah lahir dan segera terjadi kontak kulit antara bayi dan ibu setelah lahir (WHO, 2017). Pemberian ASI segera setelah melahirkan memberikan banyak manfaat bagi ibu dan bayi. Berdasarkan penelitian Edmond et al (2006) Inisiasi Menyusu Dini (IMD) dalam satu jam akan mengurangi kematian neonatal sebesar 22 persen. Jika dilakukan pada rentang waktu 1 sampai 24 jam, maka akan mengurangi kematian neonatal sebesar 16 persen dan jika dilakukan lebih dari 24 jam, maka akan meningkatkan kematian neonatal sebesar 2,4 kali. Bayi yang diberikan IMD, hasilnya 8 kali lebih berhasil dalam pemberian ASI eksklusif selanjutnya.

WHO pada tahun 2003 mengklasifikasikan implementasi IMD menjadi empat kategori, yaitu poor (0-29,9\%), fair (30-49,9\%), good (50-89,9\%) dan very good (90$100 \%$ ). Menurut SDKI 2017, secara nasional persentase yang mulai diberi ASI dalam 1 jam terakhir sebesar 56,5 persen. Dari hal tersebut dapat diketahui bahwa Indonesia sudah termasuk kategori "good" atau baik. Walaupun sudah mendapat kategori yang baik, namun masih ada terdapat beberapa provinsi yang mempunyai nilai persentase IMD dibawah persentase IMD nasional, seperti Provinsi Sumatera Utara sebesar 24,2 persen, Provinsi Sulawesi Tengah sebesar 29,9 persen dan Provinsi Kepulauan Riau sebesar 37,8 persen. Hal tersebut menandakan bahwa persentase ibu yang menerapkan IMD di beberapa daerah masih sangat rendah, bahkan jauh di bawah persentase nasional.

Berdasarkan publikasi SDKI 2012, Provinsi Sumatera Utara menjadi provinsi dengan persentase yang mulai diberi ASI dalam 1 jam terakhir terendah yaitu sebesar 17,1 persen. Dan pada publikasi SDKI 2017, Provinsi Sumatera Utara mengalami kenaikan menjadi 24,2 persen. Walaupun mengalami kenaikan, namun Provinsi Sumatera Utara tetap menjadi provinsi persentase yang mulai diberi ASI dalam 1 jam terakhir terendah. Selain itu persentase bayi yang mulai diberi ASI dalam 1 hari di Provinsi Sumatera Utara adalah sebesar 46.6 persen, dan hanya 11,4 persen bayi yang mendapatkan ASI 
Eks/usif, yang artinya seorang ibu di Provinsi Sumatera Utara memiliki kecenderungan lebih banyak menyusui bayinya di luar waktu proses IMD.

Rendahnya persentase IMD juga menyebabkan meningkatnya angka prevelensi bayi gizi buruk, sebesar 5 persen menjadi 18,3 persen dibandingkan dengan angka tahun 2016 sebesar 13,2 persen. Persentase IMD yang rendah juga menyebabkan Provinsi Sumatera Utara berada pada kategori poor atau jelek menurut WHO. Hal tersebut menandakan bahwa persentase ibu yang menerapkan IMD di Provinsi Sumatera Utara masih kecil, bahkan jauh dibawah persentase nasional. Persentase IMD di Provinsi Sumatera Utara memang mengalami kenaikan, akan tetapi kenaikannya hanya sedikit dan belum optimal. Provinsi Sumatera Utara merupakan provinsi yang terbilang maju dibandingkan dengan provinsi lain terutama Kawasan Timur Indonesia, tetapi ternyata persentase IMD di Provinsi Sumatera Utara jauh lebih rendah daripada Kawasan Timur Indonesia seperti Papua dan Maluku. Padahal persentase wanita usia 15-49 tahun yang proses kelahiran ditolong oleh tenaga kesehatan terlatih di Provinsi Sumatera Utara lebih tinggi jika dibandingkan Kawasan Timur Indonesia yaitu 95,27 persen. Hal ini menjadi tanda tanya, mengapa Provinsi Sumatera Utara yang merupakan salah satu bagian Kawasan Barat Indonesia justru persentase IMD nya yang paling rendah. Provinsi Sumatera Utara juga termasuk menjadi penyumbang tingginya AKN di Indonesia. Sehingga IMD di Provinsi Sumatera Utara sangat perlu diperhatikan dan mendapat penanganan khusus, karena IMD adalah salah satu cara untuk mengurangi kematian neonatal.

\section{METODE}

\subsection{Landasan Teori}

Dalam penelitian ini menggunakan teori perilaku kesehatan Green sebagai dasar kerangka pikir penelitian (Lampiran 1). Teori tersebut menyatakan bahwa perilaku manusia dipengaruhi oleh dua faktor, yaitu perilaku dan non perilaku. Faktor perilaku terbentuk dari tiga faktor, yaitu: faktor predisposisi (predisposing factor), faktor pendorong (enabling factor) dan faktor penguat (reinforcement factor). Berdasarkan teori tersebut, maka variabel yang diduga memengaruhi status IMD adalah variabel umur ibu saat melahirkan, kunjungan pemeriksaan kehamilan, paritas ibu, berat badan bayi saat lahir, metode persalinan, tempat persalinan, penolong persalinan dan tingkat pendidikan suami. Unit analisis dalam penelitian ini adalah wanita usia subur yang berusia 15-49 tahun yang pernah melahirkan dalam kurun waktu 5 tahun sebelum survei (2012-2017) di Provinsi Sumatera Utara. Wanita yang pernah melahirkan dalam kurun waktu lima tahun sebelum survei digunakan sebagai unit analisis dikarenakan data yang mencakup waktu pemberian ASI pertama setelah kelahiran hanya ditanyakan kepada ibu yang pernah melahirkan dalam kurun waktu lima tahun sebelum survei. Lokus dalam penelitian ini adalah Provinsi Sumatera Utara yang dilaksanakan tahun 2017.

\subsection{Metode Pengumpulan Data}

Penelitian ini menggunakan data sekunder berupa raw data hasil Survei Demografi dan Kesehatan Indonesia (SDKI) tahun 2017. Pengumpulan data dilakukan pada tanggal 24 Juli hingga 30 September di 34 Provinsi di Indonesia oleh Badan Pusat Statistik yang bekerja sama dengan Kementrian Kesehatan (Kemenkes) dan Badan Kependudukan dan Keluarga Berencana Nasional (BKKBN). Dalam pelaksanaan SDKI 2017, terdapat empat macam kuesioner yang digunakan, yaitu untuk rumah tangga (SDKI17-RT), wanita usia subur (SDKI17-WUS), pria kawin (SDKI17-PK), dan 
remaja pria (SDKI17-RP). Raw data yang digunakan berasal dari hasil pendataan dengan kuesioner SDKI17-WUS.

Dalam pelaksanaan SDKI 2017 metode pemilihan sampel yang digunakan adalah sampling dua tahap berstrata. Tahap pertama untuk memilih sejumlah blok sensus secara probability proportional to size (PPS) sistematik dengan size jumlah rumah tangga hasil listing SP2010. Tahap kedua untuk memilih 25 rumah tangga biasa di setiap blok sensus terpilih secara sistematik dari hasil pemutakhiran rumah tangga di setiap blok sensus tersebut.

Raw data yang digunakan khusus untuk sampel yang dilakukan di Provinsi Sumatera Utara, dimana terdapat 770 wanita usia subur 15-49 tahun yang pernah melahirkan dalam kurun waktu lima tahun tahun sebelum survei. Setelah dilakukan pengecekan terhadap data, ternyata terdapat missing atau non-respons dibeberapa variabel independen pada amatan tersebut, sehingga amatan tersebut tidak bisa diikutsertakan dalam penelitian ini. Sehingga jumlah amatan akhir tersisa sebanyak 744 amatan.

\subsection{Metode Analisis}

Metode analisis yang digunakan dalam penelitian ini adalah analisis deskriptif dan analisis inferensia. Analisis deskriptif yang digunakan adalah tabel dan grafik untuk melihat gambaran umum status IMD berdasarkan karakteristik wanita usia 15-49 tahun, sedangkan analisis inferensia yang digunakan adalah regresi logistik biner untuk mengetahui variabel-variabel yang memengaruhi status IMD dan kecenderungannya. Tahapan-tahapan dalam analisis regresi logistik biner adalah sebagai berikut:

\section{Pendugaan Parameter dan Pembentukan Model}

Metode yang dapat digunakan untuk mengestimasi nilai-nilai parameter yang belum diketahui pada regresi logistik biner adalah pendugaan dengan metode Maximum Likelihood Estimator (MLE). Pada umumnya penggunaan metode maksimum likelihood akan menghasilkan dugaan nilai parameter yang akan memaksimalkan peluang dari data-data yang diamati dengan menggunakan sebuah fungsi yang disebut likelihood function. Metode ini merupakan metode iterasi yang sulit dilakukan secara manual untuk mencari nilai estimasi $\beta$, sehingga penyelesainnya menggunakan perangkat lunak program pengolahan logistik untuk memperoleh nilai $\beta$ yang merupakan hasil dari penyelesaian persamaan. Persamaan regresi logistik status IMD yang akan dibentuk dalam penelitian ini adalah sebagai berikut:

$$
\hat{g}(\mathrm{x})=\hat{\beta}_{0}+\hat{\beta}_{1} \text { Umur }+\hat{\beta}_{21} \text { PendidikanIbu }+\hat{\beta}_{22} \text { PendidikanIbu }+\hat{\beta}_{3} \text { ANC }+\hat{\beta}_{4} \text { Paritas }+\hat{\beta}_{5}
$$
BBayi +

$$
\hat{\beta}_{6} \text { Metode }+\hat{\beta}_{7} \text { Tempat }+\hat{\beta}_{8} \text { Penolong }+\hat{\beta}_{91} \text { PendidikanSuami }+\hat{\beta}_{92} \text { PendidikanSuami }
$$

Keterangan:

$$
\begin{array}{ll}
\hat{g}(\mathrm{x}) & =\text { Fungsi logit } \\
\hat{\beta}_{0} & =\text { Konstanta } \\
\hat{\beta}_{1} \text { Umur } & =\text { Koefisien umur ibu saat melahirkan } \\
\hat{\beta}_{21} \text { PendidikanIbu } & =\text { Koefisien tingkat pendidikan ibu kategori menengah }
\end{array}
$$


$\hat{\beta}_{22}$ PendidikanIbu $=$ Koefisien tingkat pendidikan ibu kategori tinggi.

$\hat{\beta}_{3}$ ANC $\quad=$ Koefisien kunjungan pemeriksaan kehamilan

$\hat{\beta}_{4}$ Paritas $\quad=$ Koefisien paritas

$\hat{\beta}_{5}$ BBayi $\quad=$ Koefisien berat badan bayi saat lahir

$\hat{\beta}_{6}$ Metode $\quad=$ Koefisien metode persalinan

$\hat{\beta}_{7}$ Tempat $\quad=$ Koefisien tempat persalinan

$\hat{\beta}_{8}$ Penolong $\quad=$ Koefisien penolong persalinan

$\hat{\beta}_{91}$ PendidikanSuami $=$ Koefisien tingkat pendidikan suami kategori menengah

$\hat{\beta}_{92}$ PendidikanSuami $=$ Koefisien tingkat pendidikan suami kategori tinggi .

\section{Pengujian Kesesuaian Model (Goodness of Fit Test)}

Pada model regresi logistik biner, uji kesesuaian model menggunakan Hosmer and Lemeshow Goodness of fit test. Hipotesis yang digunakan adalah:

$H_{0}$ : Model yang dibentuk sesuai (tidak terdapat perbedaan hasil antara observasi dan hasil prediksi dari model).

$H_{1}$ : Model yang dibentuk tidak sesuai (terdapat perbedaan hasil antara observasi dan hasil prediksi dari model).

Uji kesesuaian model ini dilakukan dengan Uji $\hat{C}$. Statistik uji $\hat{C}$ ini mengikuti distribusi ChiSquare $\left(X^{2}\right)$ dengan derajat bebas 11 . Kemudian pada tingkat signifikansi 5 persen, dasar pengambilan keputusannya adalah jika nilai statistik uji $\hat{C}<\chi_{(0,05 ; 11)}^{2}$ atau $p$-value $>$ a $(0,05)$ maka gagal tolak $H_{0}$. Jika keputusannya gagal tolak $H_{0}$ maka dapat disimpulkan bahwa model yang terbentuk sesuai atau tidak terdapat perbedaan hasil antara observasi dengan prediksi dari model (Hosmer \& Lemeshow, 2000).

Untuk melihat ketepatan model, dapat juga dilihat dari tabel klasifikasi. Tabel klasifikasi berfungsi untuk menguji besarnya ketepatan model dalam memprediksi data observasi. Ketepatan model dalam memprediksi dapat dilihat dari nilai overall percentage. Semakin besar nilai overall percentage, maka semakin baik pula model dalam mengklasifikasikan variabel dependen. Dan sebaliknya, semakin kecil nilainya maka semakin tidak baik model dalam mengklasifikasikan variabel dependen.

\section{Pengujian Signifikansi Penduga Parameter dalam Model Pengujian Pendugaan Parameter Secara Simultan}

Uji simultan pada penelitian ini dilakukan dengan statistik uji G (Likelihood Ratio Test). Hipotesis yang diuji sebagai berikut:

$H_{0}: \beta_{1}=\beta_{2}=\ldots=\beta_{11}=0$ (tidak ada pengaruh variabel independen secara simultan terhadap status IMD). 
$H_{1}$ : Minimal ada satu $\beta_{j} \neq 0$ (minimal ada satu variabel independen yang berpengaruh secara simultan terhadap status IMD).

Kemudian pada tingkat signifikansi 5 persen, dasar pengambilan keputusannya adalah jika nilai statistik uji G $>, \chi_{(0,05 ; 11)}^{2}$ atau $p$-value $<$ a $(0,05)$ maka tolak $H_{0}$. Jika hasilnya tolak $H_{0}$ maka dapat disimpulkan bahwa minimal terdapat satu variabel independen yang berpengaruh terhadap variabel dependen secara simultan. Sedangkan jika gagal tolak $H_{0}$ maka tidak ada pengaruh variabel independen secara simultan terhadap variabel dependen (Hosmer \& Lemeshow, 2000).

\section{Pengujian Pendugaan Parameter Secara Parsial}

Jika pengujian secara simultan menghasilkan tolak $H_{0}$, maka langkah selanjutnya dilakukan pengujian secara parsial, menggunakan statistik uji Wald. Hipotesis yang digunakan sebagai berikut:

$H_{0}: \beta_{j}=0$ (tidak ada pengaruh variabel independen ke-j terhadap status IMD secara parsial).

$H_{1}: \beta_{j}>0$ (ada pengaruh positif antara variabel independen ke-j terhadap status IMD secara parsial).

Statistik uji Wald ini mengikuti distribusi Chi-Square $\left(X^{2}\right)$ dengan derajat bebas 1 . Kemudian pada tingkat signifikansi (a), pengambilan keputusannya adalah tolak $H_{0}$ jika nilai statistik uji $W_{j}>$ $\chi_{(0,05 ; 1)}^{2}$ atau $p$-value $<$ a $(0,05)$. Jika hasilnya tolak $H_{0}$ maka dapat disimpulkan bahwa variabel independen ke-j yang berpengaruh terhadap variabel dependen secara parsial. Sedangkan jika gagal tolak $H_{0}$ maka tidak ada pengaruh variabel independen ke-j terhadap variabel dependen secara parsial (Hosmer \& Lemeshow, 2000).

\section{Rasio Kecenderungan (Odds Ratio)}

Rasio kecenderungan (Odds ratio) adalah ukuran yang digunakan untuk menginterpretasikan hasil yang diperoleh. Dalam penelitian ini, odds ratio digunakan untuk mengetahui seberapa besar kecenderungan setiap variabel independen terhadap variabel dependen yaitu status Inisiasi Menyusu Dini (IMD).

\section{HASIL DAN PEMBAHASAN}

\section{Analisis Deskriptif}

Berdasarkan hasil pengolahan data, gambaran wanita usia 15-49 tahun yang melakukan IMD segera setelah melahirkan dapat dilihat pada gambar berikut: 


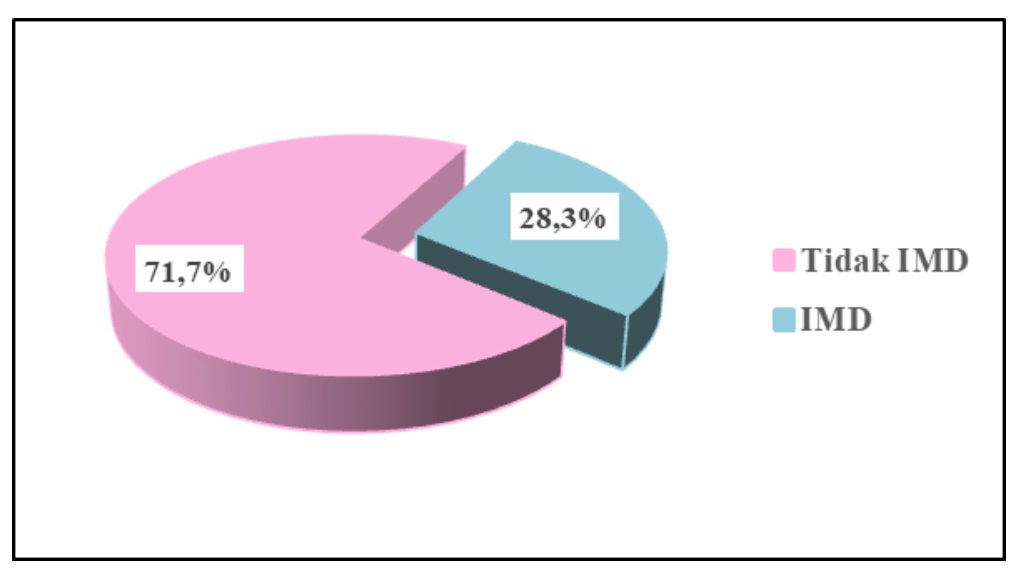

Sumber: SDKI 2017, diolah.

Gambar 1. Persentase status IMD wanita usia 15-49 tahun di Provinsi Sumatera tahun 2017.

Berdasarkan gambar 1, diperkirakan terdapat sebesar 28,3 persen wanita usia 15-49 tahun yang pernah melahirkan dalam waktu lima tahun sebelum pencacahan di Provinsi Sumatera Utara tahun 2017 yang telah melaksanakan IMD atau memberikan ASI pertama dalam waktu kurang dari satu jam setelah melahirkan. Sementara lebih dari setengah atau tepatnya 71,7 persen wanita usia 15-49 tahun yang pernah melahirkan dalam waktu lima tahun sebelum pencacahan di Provinsi Sumatera Utara tidak melaksanakan IMD atau memberikan ASI pertama dalam waktu lebih dari satu jam setelah melahirkan. Sehingga diperkirakan hanya sekitar 3 dari 10 wanita usia 15-49 tahun yang melakukan IMD segera setelah melahirkan di Provinsi Sumatera Utara tahun 2017. Hal tersebut menunjukan bahwa penerapan IMD di Provinsi Sumatera Utara masih rendah, serta masih kurangnya kesadaran ibu di Provinsi Sumatera Utara akan pentingnya IMD.Untuk memudahkan dalam hal menginterpretasi, maka selanjutnya wanita usia 15-49 tahun yang pernah melahirkan dalam periode lima tahun sebelum pencacahan akan disebut sebagai ibu.

Tabel 1. Persentase karakteristik wanita usia 15-49 tahun berdasarkan status IMD di Provinsi Sumatera Utara tahun 2017.

\begin{tabular}{|l|l|l|c|c|}
\hline No. & \multicolumn{1}{|c|}{ Variabel Independen } & \multicolumn{1}{|c|}{$\begin{array}{c}\text { Kategori Variabel } \\
\text { Independen }\end{array}$} & \multicolumn{2}{c|}{ Status IMD (\%) } \\
\cline { 4 - 5 } & & \multicolumn{1}{|c}{$(3)$} & $(4)$ & $(5)$ \\
\hline$(1)$ & $(2)$ & \multicolumn{1}{|c|}{ IMD } & Tidak IMD \\
\hline 1. & Umur Ibu Saat Melahirkan & $15-19$ tahun* & $29,6 \%$ & $70,4 \%$ \\
& & $20-35$ tahun & $31,7 \%$ & $68,3 \%$ \\
& & $36-49$ tahun & $27,1 \%$ & $72,9 \%$ \\
\hline 2. & Tingkat Pendidikan Ibu & Dasar* & $27,8 \%$ & $72,2 \%$ \\
& & Menengah & $24,6 \%$ & $75,4 \%$ \\
& & Tinggi & $28,9 \%$ & $71,1 \%$ \\
\hline 3. & Kunjungan Pemeriksaan & $<4$ kali* & $28,1 \%$ & $71,9 \%$ \\
\hline
\end{tabular}




\begin{tabular}{|l|l|l|c|c|}
\hline & Kehamilan & $\geq 4$ kali & $28,8 \%$ & $71,2 \%$ \\
\hline 4. & Paritas Ibu & 1 anak (Primipara)* & $16,8 \%$ & $83,2 \%$ \\
& & $>1$ anak (Multipara) & $32,3 \%$ & $67,7 \%$ \\
\hline 5. & BB Bayi saat Lahir & BBLR* & $26,9 \%$ & $73,1 \%$ \\
\hline 6. & Metode Persalinan & Normal & $36,5 \%$ & $63,5 \%$ \\
\hline 7. & Tempat Persalinan & Sesar* & $7,9 \%$ & $92,1 \%$ \\
& & Normal & $34,8 \%$ & $65,2 \%$ \\
\hline 8. & Penolong Persalinan & Tidak Fasilitas & $25,7 \%$ & $74,3 \%$ \\
& & Kesehatan* & $33,1 \%$ & $66,9 \%$ \\
& & Fasilitas Kesehatan & & \\
\hline 9. & Tingkat Pendidikan Suami & Tidak Tenaga & $27,8 \%$ & $72,7 \%$ \\
& & Kesehatan* & $33,3 \%$ & $66,7 \%$ \\
\hline & & Tenaga Kesehatan & & $76,7 \%$ \\
\hline
\end{tabular}

Sumber: SDKI 2017, diolah.

Dilihat dari umur ibu, persentase ibu yang menerapkan IMD pada kelompok ibu yang berusia 15-19 tahun adalah 29,6 persen, sedangkan yang tidak menerapkan IMD sebesar 70,4\% persen. Kemudian pada kelompok usia 20-35 tahun yang menerapkan IMD adalah sebesar 31,7 persen dan yang tidak menerapkan IMD adalah sebesar 68,3 persen. Dan ibu yang berusia 36-49 tahun yang menerapkan IMD adalah sebesar 27,1 persen dan yang tidak menerapkan adalah sebesar 72,9\%. Hal ini menunjukan bahwa proporsi ibu dengan kelompok usia 20-35 tahun lebih banyak yang menerapkan IMD dibandingkan dengan ibu kelompok usia 20-35 tahun. Untuk ibu yang memiliki pendidikan dasar dan menerapkan IMD adalah sebesar 27,8 persen dan yang tidak menerapkan adalah sebesar 72,2 persen. Sedangkan ibu dengan pendidikan menengah yang menerapkan IMD adalah sebesar 24,6 persen dan yang tidak menerapkan sebesar 75,4 persen. Untuk ibu yang berpendidikan tinggi, sebesar 28,9 persen telah menerapkan IMD dan sisanya yaitu sebesar 71,1 persen tidak menerapkan IMD.

Berdasarkan banyaknya kunjungan pemeriksaan kehamilan, ibu yang melakukan IMD dengan kunjungan pemeriksaan kehamilan kurang dari empat kali sebesar 28,1 persen dan ibu yang tidak melakukan IMD sebesar 71,9 persen. Sedangkan persentase ibu dengan kunjungan pemeriksaan kehamilan minimal empat kali atau lebih yang melakukan IMD adalah sebesar 28,8 persen sedangkan ibu yang tidak melakukan IMD adalah sebesar 71,2 persen. Dari hasil tersebut menunjukan bahwa ibu yang melakukan kunjungan pemeriksaan kehamilan minimal 4 kali memiliki kecenderungan lebih tinggi untuk melakukan IMD segera setelah melahirkan, dibandingkan dengan ibu yang melakukan kunjungan pemeriksaan kehamilan kurang dari 4 kali. 
Ibu yang memiliki jumlah paritas satu anak (primipara) dan melakukan IMD adalah sebesar 16,8 persen dan yang tidak melakukan adalah 83,2 persen. Sedangkan ibu yang mempunyai jumlah paritas lebih dari satu anak (multipara) dan melakukan IMD adalah sebesar 32,3 persen, sedangkan yang tidak melakukan adalah sebesar 67,7 persen. Dari hasil tersebut juga dapat terlihat bahwa ibu di Provinsi Sumatera Utara tahun 2017 yang memiliki jumlah paritas lebih dari satu anak (multipara) lebih berpotensi untuk melakukan IMD dibandingkan ibu yang berparitas hanya satu anak (primipara). Persentase ibu yang melakukan IMD dan memiliki bayi dengan BBLR atau kurang dari 2,5 kilogram sebesar 26,9 persen dan yang tidak melakukan IMD sebesar 73,1 persen. Sedangkan ibu yang melakukan IMD dan memiliki bayi dengan berat badan normal atau minimal 2,5 kilogram adalah sebesar 36,5 persen dan yang tidak melakukan IMD adalah sebesar 63,5 persen. Sehingga ibu yang melahirkan bayi dengan berat badan normal cenderung lebih menerapkan IMD segera setelah melahirkan.

Ibu yang melahirkan secara sesar sebanyak 7,9 persen melakukan IMD dan sisanya yaitu 92,1 persen tidak melaksanakan IMD. Sedangkan ibu yang melakukan persalinan secara normal sebesar 34,8 persen menerapkan IMD dan yang tidak menerapkan IMD adalah sebesar 65,2 persen. Sehingga ibu yang melakukan metode persalinan secara normal lebih cenderung untuk melakukan IMD. Ibu yang melakukan persalinan di bukan fasilitas kesehatan dan menerapkan IMD adalah sebesar 25,7 persen dan yang tidak menerapkan IMD adalah sebesar 74,3 persen. Sedangkan ibu yang melakukan persalinan di tempat yang tersedia fasilitas kesehatan dan menerapkan IMD adalah sebesar 33,1 persen dan yang tidak menerapkan IMD yakni sebesar 66,9 persen. Hal ini menunjukkan bahwa ibu yang melahirkan di tempat fasilitas kesehatan lebih banyak yang melakukan IMD, dibandingkan dengan ibu yang melahirkan bukan di tempat fasilitas kesehatan.

Persentase ibu yang melakukan IMD ditolong oleh bukan tenaga kesehatan sebesar 27,8 persen dan ibu yang tidak melakukan IMD ditolong oleh bukan tenaga kesehatan adalah sebesar 72,7 persen. Sedangkan ibu yang melakukan IMD dan persalinannya ditolong oleh tenaga kesehatan adalah sebesar 33,3 persen dan yang tidak melakukan IMD adalah 66,7 persen. Sehingga persentase ibu yang melakukan IMD segera setelah melahirkan lebih banyak terjadi pada ibu yang persalinannya dibantu oleh tenaga kesehatan. Ibu yang memiliki suami bependidikan dasar (tidak bersekolah dan SD) lebih banyak yang tidak melaksanakan IMD yaitu sebesar 76,3 persen dan sisanya sebesar 23,70 persen melakukan IMD segera setelah melahirkan. Sedangkan ibu yang memiliki suami berpendidikan menengah (SMP dan SMA) sebesar 22,5 persen melaksanakan IMD, dan yang tidak melaksanakan IMD adalah sebesar 77,5 persen. Kemudian ibu dengan suami berpendidikan tinggi (SMA keatas) sebesar 30,7 melaksanakan IMD dan sisanya yaitu 69,3 persen tidak melaksanakan IMD atau sekitar 3 dari 10 ibu yang memiliki suami berpendidikan tinggi telah melakukan IMD segera setelah melahirkan. Sehingga dapat diketahui bahwa ibu yang melaksanakan IMD lebih banyak ditemukan pada ibu yang memiliki suami berpendidikan tinggi (SMA keatas) dibandingkan dengan ibu yang suaminya berpendidikan dasar (tidak bersekolah dan SD) dan berpendidikan menengah (SMP-SMA).

\section{Analisis Inferensia}

Hasil yang diperoleh dari analisis regresi logistik biner adalah sebagai berikut:

\section{Uji Kesesuaian Model (Goodness of Fit Test)}


Pada uji kesesuaian model, uji yang digunakan adalah uji Hosmer and Lameshow untuk melihat apakah model yang digunakan sudah tepat atau telah sesuai untuk menjelaskan variabel status IMD di Provinsi Sumatera Utara tahun 2017. Hasil pengujian menggunakan uji Hosmer and Lameshow adalah sebagai berikut:

Tabel 2. Uji Hosmer and Lameshow

\begin{tabular}{|c|c|c|c|}
\hline Nilai Statistik & Nilai Statistik Tabel & $p$-value & Keputusan \\
Uji Hosmer and Lameshow & & & \\
\hline$(1)$ & $(2)$ & $(3)$ & $(4)$ \\
\hline 4,3766 & $\chi^{2}(0,05 ; 11)=19,675$ & 0,8216 & Gagal tolak $\mathrm{H}_{0}$ \\
\hline
\end{tabular}

Sumber: SDKI 2017, diolah.

Pada tabel Hosmer and Lameshow Test, nilai Chi-Square adalah 4,3766 dan p-value sebesar 0,8216 . Nilai statistik uji tersebut kurang dari $\chi_{(0,05 ; 11)}^{2}(19,675)$ dan nilai $p$-value $(0,8216)$ lebih besar dari a $(0,05)$. Dengan demikian, keputusan yang diambil adalah gagal tolak H0, oleh karena itu dengan tingkat signifikansi 5 persen dapat disimpulkan bahwa model yang terbentuk adalah fit (cocok) atau model tersebut telah sesuai. Dari hasil tersebut dapat dikatakan bahwa tidak ditemukan perbedaan yang signifikan antara observasi dan prediksi sehingga model ini layak digunakan, atau dengan kata lain model yang terbentuk mampu memprediksi dengan benar status IMD di Provinsi Sumatera Utara tahun 2017

\section{Ketepatan Klasifikasi Model Regresi Logistik Biner}

Tabel klasifikasi dapat berfungsi untuk menguji seberapa besarnya ketepatan model dalam memprediksi data observasi. Berikut merupakan tabel ketepatan klasifikasi model regresi logistik biner:

Tabel 3. Ketepatan klasifikasi model regresi logistik biner

\begin{tabular}{|c|c|c|c|c|}
\hline \multirow{2}{*}{ Observasi } & \multicolumn{3}{c|}{ Prediksi } \\
\cline { 3 - 5 } & \multicolumn{2}{|c|}{ Status IMD } & \multirow{2}{*}{ Persentase Ketepatan } \\
\cline { 2 - 5 } & Tidak IMD & IMD & \\
\hline Status IMD & Tidak IMD & 525 & 11 & 97,9 \\
\hline & IMD & 202 & 6 & 2,9 \\
\hline overall percentage & & & & 71,4 \\
\hline
\end{tabular}

Sumber: SDKI 2017, diolah.

Ketepatan model dalam memprediksi dilihat dari nilai overall percentage. Semakin besar nilainya maka mengindikasikan bahwa semakin baik model dalam mengklasifikasikan variabel 
dependen yaitu status IMD. Sebaliknya semakin kecil nilainya maka mengindikasikan bahwa semakin tidak baik model dalam mengklasifikasikan variabel dependen. Nilai ketepatan klasifikasi pada model regresi logistik biner adalah sebesar 71,4 persen dalam memprediksi status IMD. Sehingga dapat disimpulkan bahwa variabel-variabel independen dalam model dapat mengkategorikan ibu yang melakukan IMD dan tidak melakukan IMD dengan ketepatan 71,4 persen.

\section{Pengujian Pendugaan Parameter Secara Simultan}

Tabel 4. Hasil uji simultan.

\begin{tabular}{|c|c|c|c|}
\hline Nilai Statistik Uji G & $\begin{array}{c}\text { Nilai Statistik Chi-square } \\
\text { Tabel }\end{array}$ & $p$-value & Keputusan \\
\hline$(1)$ & $(2)$ & $(3)$ & $(4)$ \\
\hline 88,52 & $\chi_{(0,05 ; 11)}^{2}=19,675$ & 0,000 & Tolak $\mathrm{H}_{0}$ \\
\hline
\end{tabular}

Sumber: SDKI 2017, diolah.

Berdasarkan hasil pengolahan data tersebut, nilai statistik uji G dapat dilihat pada tabel Omnibus Test of Model Coefficients yang kemudian dibandingkan dengan nilai Chi-Square yaitu sebesar $\chi^{2}(0,05 ; 11)$ atau $p$-value dibandingkan dengan nilai tingkat signifikansi 5 persen. Nilai $\mathrm{G}$ sebesar $(88,52)>\chi^{2}(0,05 ; 11)(19,675)$ dan nilai $p$-value $(0,000)<0,05$ maka keputusan yang diambil adalah tolak $\mathrm{H}_{0}$. Sehingga dapat disimpulkan bahwa dengan tingkat signifikansi sebesar 5 persen minimal ada satu variabel bebas dari variabel independen umur ibu saat melahirkan, tingkat pendidikan ibu, kunjungan pemeriksaan kehamilan, paritas ibu, berat badan bayi saat lahir, metode persalinan, tempat persalinan, penolong persalinan dan tingkat pendidikan suami yang berpengaruh terhadap variabel status IMD di Provinsi Sumatera Utara tahun 2017.

\section{Pengujian Pendugaan Parameter Secara Parsial}

Pada hasil uji simultan dapat disimpulkan bahwa minimal terdapat satu variabel independen dari sepuluh variabel independen yang berpengaruh terhadap variabel status IMD di Provinsi Sumatera Utara tahun 2017. Sehingga dapat dilanjutkan pengujian secara parsial, untuk mengetahui variabel independen mana yang berpengaruh signifikan terhadap status IMD. Statistik uji yang digunakan adalah Uji Wald (Wald Test). Hasil pengolahan uji parsial secara lengkap yaitu:

Tabel 5. Hasil uji parsial.

\begin{tabular}{|c|c|c|c|c|}
\hline \multicolumn{1}{|c|}{ Variabel } & $\begin{array}{c}\text { Nilai } \\
\text { Koefisien ( } \\
\widehat{\boldsymbol{\beta}})\end{array}$ & SE & $\begin{array}{c}\text { Nilai } \\
\text { Statistik } \\
\text { Wald }\end{array}$ & p-value \\
\hline$(1)$ & $(2)$ & $(3)$ & $(4)$ & $(5)$ \\
\hline Umur Ibu saat Melahirkan(1) & $-0,43183$ & 0,48205 & 0,802 & 0,3703 \\
\hline Umur Ibu saat Melahirkan(2) & $-0,19604$ & 0,52628 & 0,139 & 0,7095 \\
\hline Tingkat Pendidikan Ibu (1) & 0,26913 & 0,24438 & 1,213 & 0,2708 \\
\hline
\end{tabular}




\begin{tabular}{|l|c|c|c|c|}
\hline Tingkat Pendidikan Ibu (2) & 0,39732 & 0,35242 & 1,271 & 0,2596 \\
\hline Kunjungan Pemeriksaan Kehamilar & 0,38855 & 0,23676 & 2,693 & 0,1008 \\
\hline Paritas Ibu(1) & 0,96660 & 0,24474 & 15,598 & $0,0000^{*}$ \\
\hline Berat Badan Bayi saat Lahir(1) & 0,67409 & 0,30937 & 4,748 & $0,0293^{*}$ \\
\hline Metode Persalinan(1) & 1,90984 & 0,30292 & 39,749 & $0,000 *^{*}$ \\
\hline Tempat Persalinan(1) & 0,15680 & 0,20618 & 0,578 & 0,4469 \\
\hline Penolong Persalinan & 0,08643 & 0,38187 & 0,051 & 0,8209 \\
\hline Tingkat Pendidikan Suami(1) & 0,53386 & 0,24590 & 4,713 & $0,029 *^{*}$ \\
\hline Tingkat Pendidikan Suami(2) & 0,22895 & 0,38689 & 0,350 & 0,5540 \\
\hline Kostanta & $-4,13126$ & 0,73912 & 31,241 & 0,0000 \\
\hline
\end{tabular}

Sumber: SDKI 2017, diolah.

Keterangan: ${ }^{*}$ ) Signifikansi pada $\alpha=5$ persen

Berdasarkan tabel 5, diperoleh kesimpulan bahwa dengan tingkat signifikansi 5 persen maka variabel-variabel yang berpengaruh terhadap status IMD di Provinsi Sumatera Utara tahun 2017 adalah paritas ibu, berat badan bayi saat lahir, metode persalinan dan tingkat pendidikan suami. Sedangkan pada tingkat signifikansi yang sama, variabel umur ibu saat melahirkan, kunjungan pemeriksaan kehamilan, tempat persalinan dan penolong persalinan tidak memengaruhi.

Berdasarkan hasil pengujian ketepatan model, pengujia secara simultan dan parsial maka persamaan regresi logistik yang dihasilkan sebagai berikut:

$\hat{g}(\mathrm{x})=-4,13126-0,43183 \mathrm{Umur}(1)-0,19604(2)+0,26913 \mathrm{ANC}+0,96660$ Paritas* + 0,67409BBBayi* ${ }^{+}$1,90984Metode* + 0,15680Tempat + 0,08643Penolong + 0,53386Pendidikan(1)* 0,22895Pendidikan(2)

Keterangan: ${ }^{*}$ ) signifikansi pada $\mathrm{a}=5$ persen

\section{Rasio Kecenderungan (Odds Ratio)}

Tabel 6. Nilai odd ratio

\begin{tabular}{|l|c|}
\hline \multicolumn{1}{|c|}{ Variabel } & $\operatorname{Exp}(\widehat{\boldsymbol{\beta}})$ \\
\hline$(1)$ & $(2)$ \\
\hline Paritas Ibu(1) & 2,6289 \\
\hline Berat Badan Bayi saat Lahir(1) & 1,9622 \\
\hline Metode Persalinan(1) & 6,7520 \\
\hline
\end{tabular}




\begin{tabular}{|l|c|}
\hline Tingkat Pendidikan Suami(1) & 1,7054 \\
\hline Tingkat Pendidikan Suami(2) & 1,2572 \\
\hline
\end{tabular}

Sumber: SDKI 2017, diolah.

Seorang ibu yang memiliki jumlah anak lebih dari satu (multipara) memiliki kecenderungan sebesar 2,6289 kali lebih besar untuk melakukan IMD dibandingkan dengan ibu yang paritasnya 1 anak (primipara), dengan asumsi variabel lain konstan. Hal ini sejalan dengan penelitian Acharya \& Khanal (2015). Acharya dan Khanal mengemukakan adanya hubungan antara jumlah anak dengan waktu pemberian ASI pertama setelah kelahiran. Ibu yang memiliki anak hanya satu (primipara) cenderung kesulitan dalam melaksanakan IMD, hal ini dikarenakan kurangnya pengalaman serta kurangnya rasa percaya diri, berbeda dengan ibu multipara yang sudah memiliki pengalaman sebelumnya dalam hal menyusui. Sehingga paritas memiliki hubungan yang positif terhadap praktik IMD, dimana ibu yang memiliki anak lebih dari satu (multipara) akan cenderung untuk melakukan praktik IMD dibandingkan ibu yang memiliki hanya satu (primipara).

Ibu yang melahirkan bayinya dengan berat badan normal memiliki kecenderungan sebesar 1,962 kali untuk melakukan IMD dibandingkan dengan ibu yang melahirkan bayi dengan BBLR, dengan asumsi variabel lain konstan. Hal ini dikarenakan bayi yang lahir dengan berat badan lahir rendah memiliki kemampuan refleks mengisap yang lemah sehingga ASI harus dikeluarkan secara manual dan diberikan pada bayi karena bayi tidak dapat mengisap sendiri ASI dari ibunya. Selain itu bayi dengan berat badan lahir rendah membutuhkan perawatan intensif sehingga kondisi bayi tidak memungkinkan untuk melakukan IMD segera setelah melahirkan. Hal ini sejalan dengan penelitian Brinch (1986), yang mengatakan bahwa bayi yang lahir lahir dengan berat badan yang kurang dari 2,5 kilogram (BBLR) ataupun bayi kembar masih dapat diberikan ASI segera setelah lahir, apalagi bayi yang lahir dengan berat badan lahir normal harus segera diberikan ASI pada 1 jam pertama setelah kelahiran, kecuali bayi tersebut dalam kondisi yang bermasalah seperti kesulitan pernapasan, sepsis dan malformasi.

Seorang ibu yang melakukan proses persalinannya dengan menggunakan metode normal cenderung untuk menerapkan IMD setelah kelahiran adalah sebesar 6,7520 kali lebih besar dibandingkan dengan ibu yang melahirkan secara sesar dengan asumsi semua variabel dianggap konstan. Hasil ini juga sejalan dengan penelitian yang dilakukan oleh Acharya dan Khanal (2015). Acharya dan Khanal mengemukakan bahwa bayi yang dilahirkan secara sesar lebih berisiko untuk tidak mendapatkan ASI segera setelah lahir. Hal ini disebabkan karena bayi yang lahir melalui operasi sesar pada umumnya akan langsung dibersihkan dan dipindahkan ke ruangan lain, sedangkan ibu yang baru saja melahirkan tersebut harus segera ditangani oleh dokter. Selain itu, ibu juga masih dalam pengaruh obat bius sehingga tidak mampu memberikan ASI segera setelah lahir kepada bayi.

Tingkat pendidikan seorang suami dapat memengaruhi ibu dalam mengambil keputusan, khususnya dalam hal melaksanakan IMD. Ibu yang memiliki suami dengan tingkat pendidikan sdang (SMP dan SMA) memiliki kecenderungan sebesar 1,7054 kali lebih besar dibandingkan dengan ibu yang memiliki suami dengan tingkat pendidikan rendah. dengan asumsi semua variabel dianggap konstan. Sedangkan ibu yang memiliki suami dengan tingkat pendidikan tinggi (SMA keatas) memiliki kecenderungan sebesar 1,2572 kali lebih besar dibandingkan dengan ibu yang memiliki suami dengan tingkat pendidikan rendah. dengan asumsi semua variabel dianggap 
konstan. Sehingga dengan kata lain semakin tinggi tingkat pendidikan suami maka cenderung akan lebih besar mendukung ibu untuk melakukan IMD segera setelah melahirkan.

\section{KESIMPULAN}

Berdasarkan hasil dan pembahasan, maka dapat diketahui bahwa persentase wanita usia 1549 tahun yang pernah melahirkan dalam waktu lima tahun sebelum pencacahan yang melakukan Inisiasi Menyusu Dini (IMD) segera setelah melahirkan di Provinsi Sumatera Utara pada tahun 2017 adalah sebesar 27,3 persen. Persentase wanita usia 15-49 tahun di Provinsi Sumatera Utara tahun 2017 yang melaksanakan Inisiasi Menyusu Dini (IMD) segera setelah melahirkan lebih tinggi terjadi pada ibu yang melahirkan pada kategori umur 20-35 tahun, melakukan kunjungan ANC minimal 4 kali, memiliki jumlah anak lebih dari satu (multipara), memiliki bayi yang lahir dengan berat badan normal, melakukan persalinan secara normal, melakukan persalinan di tempat fasilitas kesehatan dan dibantu oleh tenaga medis dan memiliki suami berpendidingan tinggi (SMA keatas).

Berdasarkan hasil analisis regresi logistik biner, didapatkan bahwa faktor-faktor yang signifikan memengaruhi status Inisiasi Menyusu Dini (IMD) segera setelah melahirkan di Provinsi Sumatera Utara pada tahun 2017 adalah paritas ibu, berat badan bayi saat lahir, metode persalinan dan tingkat pendidikan suami. Ibu yang memiliki kecenderungan lebih tinggi untuk melakukan IMD adalah ibu yang memiliki jumlah anak lebih dari satu (multipara), memiliki bayi yang lahir dengan berat badan normal, melakukan persalinan secara normal dan memiliki suami berpendidikan tinggi (SMA keatas).

\section{DAFTAR PUSTAKA}

Acharya, P., \& Khanal, V. (2015). The effect of mother's educational status on early initiation of breastfeeding: Further analysis of three consecutive Nepal Demographic and Health Surveys Global health. BMC Public Health, 15(1). https://doi.org/10.1186/s12889-015-2405-y

Aini, N., \& Budyanra. (2019). Determinan Inisiasi Menyusu Dini (IMD) Wanita Usia 15-49 Tahun di Indonesia (Analisis Data SDKI 2012). Indonesian Journal of Statistics and Its Applications, 3(1), 33-48.

Badan Pusat Statistik (BPS). (2012). Survei Demografi dan Kesehatan Indonesia 2012. Jakarta:

Badan Pusat Statistik

Badan Pusat Statistik (BPS). (2017). Survei Demografi dan Kesehatan Indonesia 2017. Jakarta: Badan Pusat Statistik

Badan Pusat Statistik. (2016). Potret Awal Tujuan Pembangunan Berkelanjutan (Sustainable

Development Goals) di Indonesia. In Katalog BPS.

Edmond, K. M., Zandoh, C., Quigley, M. A., Amenga-Etego, S., Owusu-Agyei, S., \& Kirkwood, B. R.

(2006). Delayed breastfeeding initiation increases risk of neonatal mortality. Pediatrics, $11 \pi(3)$.

https://doi.org/10.1542/peds.2005-1496

Departemen Kesehatan (Depkes). (2008). Paket Modul Kegiatan Inisiasi Menyusu Dini (IMD) dan ASI Eksklusif 6 bulan. Jakarta: Departemen Kesehatan RI

Fauziah. (2009). Faktor-faktor yang berhubungan dengan Waktu Menyusui Pertama Kali pada Bayi Baru Lahir di Rumah Sakit Umum Daerah Koja Jakarta [Skripsi]. Jakarta: Universitas Islam Negeri Syarif Hidayatullah. 
Fikawati, S., \& Syafiq, A. (2003). Hubungan Antara Menyusui Segera (Immediate Breastfeeding) dan Pemberian ASI Eksklusif Sampai dengan Empat Bulan. Jurnal Kedokteran Trisakti. 22 (2). 47-55.

Hosmer, D.W. \& Lemeshow, S. (2000). Applied Logistic Regression: Second Edition. Canada: John Wiley \& Sons, Inc.

Nelvi, (2004). Faktor-faktor yang Berhubungan dengan Inisiasi Pemberian ASI di RB Puskesmas Jakarta Pusat Tahun 2004 [Skripsi].. Jakarta: Universitas Indonesia.

World Health Organization (WHO). Child Mortality. Diakses pada tanggal 21 November 2019 melalui https://www.who.int/data/gho/data/indicators/indicator-details/GHO/maternal-mortality-ratio-(per-100$\underline{000-\text {-live-births) }}$ 